\title{
Development of a Model for Natural Disaster Mitigation on the Socialization in Elementary School
}

\author{
Ruslan Dabi Dabi ${ }^{1}$, Rugaya M Pandawa ${ }^{2}$, Damir Umanailo ${ }^{3}$ \\ ${ }^{1,2,3}$ Health Polytechnic of Ternate, North of Maluku Province, Indonesia
}

\begin{abstract}
Ternate City Central Community activity center is the densest. The high activity of this city because it is a center of trade and transport concentration of North Maluku province. The long history of eruption of Gamalama list as well as other natural disasters certainly society Ternate in General and particularly the community around the center of the explosion was targeted as well as areas prone to natural disasters has had long experience interact with the eruption of Gamalama natural disasters. Mitigation or Taming is the effort and the activities undertaken to mitigate and minimize the consequences that posed by disasters, which includes preparedness and vigilance. Mitigation is the liability of the various parties, be it experts, Governments, and society broadly. Purpose of the research conducted was to develop models of socialization of the natural disaster mitigation in the form of software fits the needs of school age children in Kelurahan of Tubo City of Ternate. The benefits of this research are expected to provide benefits to the development of science, particularly in the field of emergency nursing children and disaster management. Method; The type of Research used in this research is quantitative with the methods of research and development (research and development) is a process or steps to develop a new product or perfecting products that are already there. The populations in this study are all the Children who were in the Neighborhood Tubo Ternate city. The sample are school age children grades 4-6 SD. The location of this research is located in Village Tubo Ternate city. The location chosen for the reason that these locations include areas that are prone to natural disasters, especially due to the eruption of Gamalama volcano. Data collection Techniques used in this study are, among others, is the interview and question form questions. The next method of observation is to see firsthand the things that have been done in the mitigation of natural disasters. While the techniques of Data analysis performed with the descriptive form of statistically analyzed average and percentage to analyze data. Qualitative analysis was conducted to describe the resulting data through the observation and documentation study. Research results on a search against the use of interactive learning media preferred by school age children, understanding the child against a learning more can be absorbed properly by involving many use the sensorial. The results of the tests showed the presence of model learning media interest and interest to want to learn using interactive media. Local relevant agencies are expected to be able to support the efforts of this interactive media products in order to increase knowledge of the effort can be realized even more.
\end{abstract}

Keywords: Models of socialization, Mitigation of natural disasters, Children of school age.

\section{Introduction}

Geographically Indonesia is an archipelago that is located at the confluence of four tectonic plates, that plate of Asia, Australia, the Indian Ocean and the Pacific Ocean. Ternate City Central Community activity center is the densest. The high activity of this city is because it is a center of trade and transport concentration of North Maluku province. In addition lies the town of Ternate was under a foot of Gamalama volcano the most active issuing volcanic ash, recorded the last five years this mount Gamalama erupted more than five times (BMKG Ternate city, 2014).

The disaster is a functioned serious disorder a society causing widespread loss of human life, both in the economy, public order or the environment. The disaster poses a lot of various sorrows and losses, because that's what POPs management disaster management or better known as the mitigation of disasters.

Mitigation (mitigate) means actions to reduce the dangers so that losses can be minimized. According to the decision of the Minister of Internal Affairs Indonesian Republic No. 131 Year 2003, mitigation or Taming is the effort and the activities undertaken to mitigate and minimize the consequences that posed by disasters, which includes preparedness and vigilance. Mitigation is the liability of the various parties, be it experts, Governments, and society broadly. Knowledge, understanding and preparedness need to be socialized to the community to be able to anticipate, cope, minimize losses in earlier especially for children of school age.

Preparedness also includes actions designed to improve the ability to protect your property from damage and chaos due to disasters as well as the ability to engage in the activity of retrogress and early recovery (after the Sutton \& Tierney, 2006).

Lopez et al (2012) stated that the involvement of children in disaster management provides the most positive contribution towards the rescue, recovery and rehabilitation of the disaster. The involvement of the children is a component in disaster risk reduction. The Organization of disaster relief is also on the Government Regulation No. 21 years 2008 and backed by the UN Convention on the rights of the child (1989) that children have an absolute right to participate in decisions that will eventually affect their livelihood and life in all situations including before, during and after a disaster.

According to Oemarmadi (2005), suggests that the community is of course already provided Indonesia with the 


\section{International Journal of Science and Research (IJSR) \\ ISSN (Online): 2319-7064}

Index Copernicus Value (2016): 79.57 | Impact Factor (2015): 6.391

knowledge of the dangers of natural disasters, ranging from children attending kindergarten, elementary school and later, even all members of the general public who related.

Research conducted by Rugaya dkk (2016) shows that natural disaster relief with local indigenous local wisdom can be anticipated with increased natural hazard mitigation, preparedness, establishing outposts and monitor rescue or evacuation routes for making sacrifices, and others. In addition, efforts to increase services and evaluation of actions taken can run a maximum of and supported by the whole community, both in normal conditions or during natural disasters.

Sub districts of Tubo was chosen as the locus of research for various reasons, among others, the neighborhood as an area prone to natural disasters, point due to its location near the top of the mountain and into the path of the flow of cold lava flood. According to Abdullah (2008) that is natural disaster is considered as a new experience, something that has never happened before, so it is taken as something that is not yet the collective knowledge and experience. As a result, natural disasters have not integrated in life and social policy.

The term disaster refers to an event that is associated with the effects of the great damage caused. It contains the same meaning as the term disaster (United Kingdom) which comes from the word "dis" means something awful (unfavorable) and "astro" which means the asterisk (star). Dis-astro means an event are precipitated by stars (the stars fall to Earth). Law Number 24 year 2007 explained that a disaster is an event or series of events that threaten and disrupt the lives and livelihoods of society caused, either by natural factors and/or other non-natural or human factors, resulting in the onset of human casualties, damage to the environment, loss of property, and the psychological impact (Law Number 24 year 2007, Chapter 1:1).

This condition causes the community or communities in this case children have not had adequate knowledge about a natural disaster, so it's not able to do efforts and concrete actions to reduce risks including the risk posed towards health. In accordance with previous research by Enok is "Model of socialization on the Community Mitigation of disaster-prone Areas in West Java. The advantages of the model such that is socializing can be understood by the people whereas the drawback is only done in the form of socialization model material exposure mitigation not made training-training is specifically about how to self-rescue through a simulation of the abilities and skills in order to remain back. Related to this is the reason researcher to develop models of socialization of hazard mitigation in the form of Software. Software according to the needs of school age children is for the advantages of this model of socialization can better attract the attention of children's audio visual in the following socialization of hazard mitigation. While drawbacks i.e. not all children age Milwaukee Public Basic has the HP Android \& Laptop.

\section{Method of Research}

The type of Research that is Quantitative using the methods of research and development (research and development) is a process or steps to develop new products or refine existing products. In this research will be developed in the form of the software product (the $C D$ Interactive) programs for education, training or guidance of disaster mitigation. The population in this research is school age children who were in the Neighborhood Tubo Ternate city. The sample uses Purposive sampling namely sample taken based on needs to be achieved (Arikunto, 2010). The sample amounted to 40 school-age children with the criteria as follows:

1) School age children (10-12 years).

2) Able to operationalize the computer by default

3) Children who are willing to become a participant

The location of this research is located in Village Tubo Ternate city. Data collection Techniques used in this study are, among others, is the interview and question form questions. The next method of observation is to see firsthand the things that have been done in the mitigation of natural disasters. Then study the documentation for the secondary data source is required research is sourced from the archive documents in the form of notes, recordings, pictures or photos.

In this research is the selection of informants using purposive sampling (sampling aims). Informants' researchers determine it is the people who have the needed information from Government wards, parents, teachers and BPBD the city of Ternate. The data have been analyzed by means of subsequent descriptive statistics mean and percentage form to analyze data.

\section{Result and Discussion}

The location of the research focused on the Villages located in Tubo Town North of Ternate, it is concerned because the village Tubo is under the feet of gamalama volcano. The village had a total population of Tubo 2,059 soul with the number of laki 1,025 people, men women 1,034 inhabitants. The number of children of primary school age in Kelurahan Tubo as much as 198 people. (Profile Wards Tubo, 2016).

a) Characteristics Of Respondents, The respondents in this study are the children of 4-6 primary school classes with a total of 40 people, who were in the Neighborhood Tubo.

b) Gender, Table. 1 The Distribution Of Gender

\begin{tabular}{|c|c|c|c|}
\hline No. & Gender & $\mathrm{n}$ & $\%$ \\
\hline 1 & Male & 20 & 50 \\
\hline 2 & Women & 20 & 50 \\
\hline \multicolumn{2}{|c|}{ Total } & 40 & 100 \\
\hline
\end{tabular}

In table 1 indicates that of the 40 students, the number of boys and girls 20 students totaling 20 students.

c) Digs interest in learning through the media, Table 2 Extracting the child learning interest

Volume 6 Issue 12, December 2017

www.ijsr.net

Licensed Under Creative Commons Attribution CC BY 
International Journal of Science and Research (IJSR)

ISSN (Online): 2319-7064

Index Copernicus Value (2016): 79.57 | Impact Factor (2015): 6.391

\begin{tabular}{|c|c|c|c|}
\hline NO. & Model & Interest of the Child & $(\%)$ \\
\hline 1 & Story book & 8 & 20 \\
\hline 2 & Video & 10 & 25 \\
\hline 3 & Interactive Games & 22 & 55 \\
\hline & TOTAL & $\mathbf{4 0}$ & $\mathbf{1 0 0}$ \\
\hline
\end{tabular}

From the table above, it was found that the learning interest of school children was more a desire to study the use of Interactive Gaming media as much as 22 people (55\%), desire against the media video a total of 10 people (25\%), while for children an interest in reading story book more or less i.e. 4 people $(20 \%)$. The learning process needs to involve many sensorial process, as more and more city involvement in the learning process, can affect a person's ability to understand the intent of the study (Notoatmojo, 2010).

d) Product development model for natural disaster mitigation on the socialization of children of school age.

The design of the model is done in system, the general objective in the design of this is to give you an idea about the knowledge of the volcanic disaster, health problems and how to prevention. This model assesses the user's understanding in detail and systematic. Shape design of this model in the show as follows:

1) Application System, The shape of the design in the manufacture of this model called the "POLOTE KIE" which is an interactive model. Use this interactive model that is used as the topic of the use of media of socialization of the natural disaster mitigation in children of school age in kelurahan tubo Ternate city.. Interactive media which is one of the results of the implementation of multimedia where almost all multimedia content found in one fragment Compact disc or can be stored in the flash disc which consists of pictures, video animation, text as well as in the form of a quiz game is also an assessment of the child in understanding the disaster that results in health problems and prevention can eventually figure out how to do independently. This model is in production with the application version Video ax 8 interactive, is used to describe and visualize the artifact of the process object-oriented analysis and design about the ins and outs of knowledge towards the prevention of disaster and danger due to the eruption of the volcano.

2) The Design of the User Interface, User Interface or the look of the interface is directly related to the user, use this app to be divided into a form different view that adapts to the needs of knowledge and information about the disaster. The design of this model made as attractive as possible in order for the child to feel interested in this interactive learning would do. This model is derived from the modification of the source of information about the disaster by disaster management body's regional agencies (BPBD), which is the basic foothold disaster preparedness procedure in the volcano.

3) Early appearance of the flash Screen, Early appearance of Compact Disc interactive this is an early appearance when the user begins to open the application. The main menu contains the menu book icon contained in the

application.

As many as seven fruits of the applications menu in the form of buttons with icon on the top of the menu instance in order for the user to know the search easier. Overall this media using the soft colors tend to be adapted to the natural form of the sky bluish situation and backgrounds of the volcano. This colorful display is possible because being a quiet contrast perceived by users of the age of the child.

\section{Model Test Results}

1) Assessment Appeal, Table. 3 Assessment Appeal

\begin{tabular}{|l|l|l|l|}
\hline No. & The Appeal Of & N & $\%$ \\
\hline 1 & Very Interesting & 28 & 70 \\
\hline 2 & Interesting & 11 & 27.5 \\
\hline 3 & Less Interesting & 1 & 2.5 \\
\hline 4 & Not Interesting & 0 & 0 \\
\hline \multicolumn{2}{|l|}{ Total } & 40 & 100 \\
\hline
\end{tabular}

In table .3 show that of the 40 students most of the points that the interactive media applications very interesting IE as much as 28 students.

2)Assessment of the Efficiency, Table. 4 the assessment of Efficiency

\begin{tabular}{|l|l|l|l|}
\hline No. & The efficiency of the & N & $\%$ \\
\hline 1 & It Is Very Easy & 24 & 60 \\
\hline 2 & Easy & 14 & 35 \\
\hline 3 & Somewhat Difficult & 2 & 5 \\
\hline 4 & It Is Very Difficult & 0 & 0 \\
\hline \multicolumn{2}{|l|}{ Total } & 40 & 100 \\
\hline
\end{tabular}

In table 4 show that of the 40 students most of the points that the interactive media application is very easy in use i.e. as many as 24 students.

3) Benefit Evaluation, Table. 5 assessment of the expediency
of
\begin{tabular}{|l|l|c|c|}
\hline No. & The Appeal of & N & $\%$ \\
\hline 1 & Very Familiar & 22 & 55 \\
\hline 2 & Understand & 15 & 37.5 \\
\hline 3 & Less Familiar & 3 & 7.5 \\
\hline 4 & Very Less Familiar & 0 & 0 \\
\hline Total & & 40 & 100 \\
\hline
\end{tabular}

In table 5 show that of the 40 students that applications address the most interactive media is so familiar that is as much as 22 students.

\section{Conclusion}

Government authorities nationwide to examine and analyze the symptoms of disaster are BMG, to then be informed to BNPB (National Agency for disaster management). BNPB Doing coordination with related agencies such as BPBD and educational institutions regarding the management of disaster mitigation to such information simultaneously and socialized into communities and educational institutions in accordance 


\section{International Journal of Science and Research (IJSR) \\ ISSN (Online): 2319-7064}

Index Copernicus Value (2016): 79.57 | Impact Factor (2015): 6.391

with the capacity or the tasks of the Agency are concerned more particularly to children of school age.

At the start of a good government in Disaster Handling Agency of represent by or cooperation with related institutions, develop models of socialization of disaster which includes layout space, disaster-prone regions, map type and symptom onset disaster, disaster mitigation, evacuation maps, maps of potential vulnerabilities in catastrophe-prone areas, disaster management SOP, information system (early warning), and the book disasters and mitigation, the information is socialized through upgrading, training, education, and printed materials (books, pamphlet, brochure), media TV and radio communications. After socializing needs to follow up with training in particular self-rescue about strategy through simulation or a drill, so that the knowledge and skills remain preserved and also for government agencies is this Educational establishments in order to incorporate disaster mitigation into the curriculum in order to facilitate the learning of children in disaster preparedness.

\section{Suggestion}

Advices that can be given by a team of researchers with respect to this research are:

1) For Governments, it is Need to be disseminated map insecurity disaster, disaster mitigation and early warning systems that are effective and efficient were extensively using many medias and Material disaster need to be incorporated in the curriculum of local charge for disaster-prone areas.

2) For educators/teachers in primary schools, The results of this study are expected to provide knowledge and understanding of the teacher and the institutions of the importance of incorporating curriculum on education disaster.

3) For elementary school kids, The results of this study are expected to provide the basis for being understood of knowledge about disaster preparedness and readiness in students about disaster preparedness and resilience resources on students due to the disaster.

\section{References}

[1] Abdullah, Irwan, (2008), Konstruksi dan Reproduksi Atas Bencana Alam, Working Papers in Interdiciplanary Studies No. 1, Yogyakarta: Sekolah Pasca Sarjana Universitas Gadjah Mada.

[2] Andrew, M.M., \& Boyle, J. S 1995. Transcultural Concepts in Nursing Care. Edisi ke-2. Philadelpjia: J. B. Lippincott Company

[3] Aulawi, Akhmad, Refleksi Pengelolaan Bencana di Indonesia Antara Harapan dan Realita : Suatu Analisis Yuridis, dalamhttp://ditjenpp.kemenkumham.go.id/hukumlingkungan/1095-refleksi-pengelolaan-bencana-diindonesia-antara-harapan-dan-realita-suatu-analisisyuridis.html

[4] Arikunto 2010. Prosedur Penelitian Suatu Pendekatan Praktik, Edisi Revisi X. Rineka Cipta Jakarta.
[5] Badan Penanggulangan Bencana Daerah, (2015), Data Historis Kejadian Bencana sampai dengan akhir tahun 2015, Kota Ternate

[6] Cecep Eka Permana, (2010), Kearifan Lokal Masyarakat Baduy Dalam Mitigasi Bencana, Jakarta: Wedatama Widya Sastra.

[7] Coburn, AW, R.J.S. Spence dan A. Pomonis, 1994, Mitigasi Bencana, Cambridge Architectural Research Limited, The Oast House, Malting Lane, Cambridge, United Kingdom

[8] Fuad, Anis dan Kandung S. Nugroho, (2014), Panduan Praktis Penelitian Kualitatif, Serang: Graha Ilmu.

[9] Galla, A., (2001), Guidebook for the Participation of Young People in Heritage Conservation, Brisbane: Hall and Jones Advertising.

[10] Iskandar, J., Mitigasi Bencana Lewat Kearifan Lokal, dalam Kompas, edisi 6 Oktober 2009, diunduh tanggal 10 Maret 2016 dari http://cetak.Kompas.com.

[11]Jackson \& Jacobs, 2008 Major Flood Hits County, Damages Many Roads. The Brazil Times

[12] Oemarmadi, S 2005 Pendidikan dan Mitigasi Educational Research. Jurnal Ilmiah Pendidikan dan Pembelajaran

[13] Priambodo.2009,Panduan Praktis Menghadapi

a. Bancana,Penerbit KanisiusYogyakarta.

[14] Rugaya, dkk (2016), Manajemen Bencana Alam Berbasisi Kearifan Lokal Masyarakat Adat Di Kota Ternate.

[15] Subiyantoro, I., Selayang Pandang Tentang Bencana, Jurnal Dialog Penanggulangan Bencana, No. 1, 2010.

[16] Sugiantoro, dkk (2010), Manajemen Bencana : Respons dan Tindakan Terhadap Bencana, Yogyakarta : Media Pressindo.

[17] Undang-Undang Nomor 24 Tahun 2007 tentang Penanggulangan Bencana

[18] Yance Arizona, Mendefinisikan Indigenous Peoples di Indonesia, dalam 